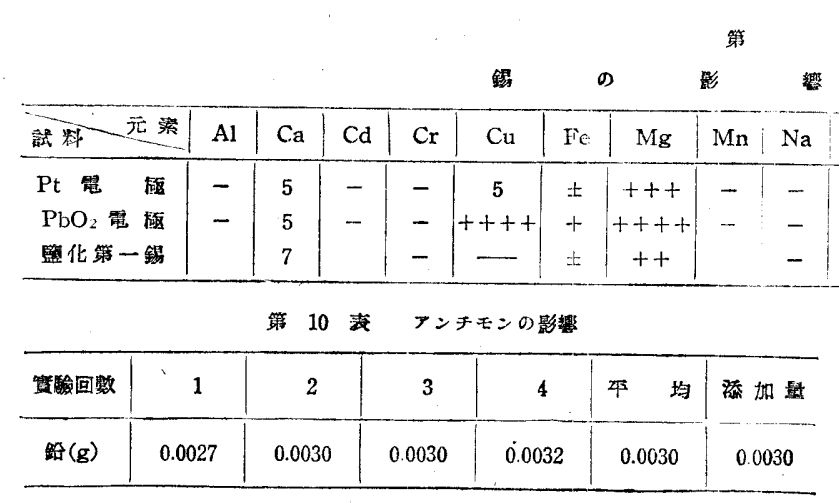

逃げる心配が無くて宜しいと思はれる.

以上合成溶液の調查により望驗 6 の作業指釗にて試料艺伃析士 れば大體 $\pm 0.01 \%$ の誤差にて定量し得ることを知つた。次に試 料に脚る。

\title{
3. バビット・メタル中の結の定量結果
}

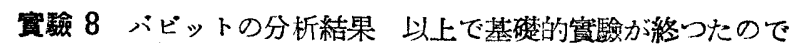

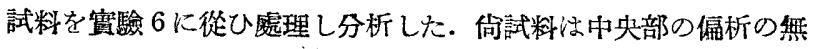
い部分より取つた. 結果を第 11 袁に示す. 相互の差も餘り多く なく，且所要時間は約 $5 \mathrm{hr}$ で完了する.

實驗 9 最㷋に第 1 圖の如き約 $8 \mathrm{~kg}$ のハ ビット鑄塊より圂示の 各所を上記電解法にて 分析するに同逼中に示 寸如き含有量であつ た. 面積の小さい方が 金型の底部に篦る。圖 に見る如く偏析は銅程 著しくない. 少くも一 方の面內では偏析はな い. 最初に固化した底 部に幾分鍇が少く後で 固まつた方に多い。

澄鍇以外に銅及びア ンチモンを定量した. 銅は前報示した電解法

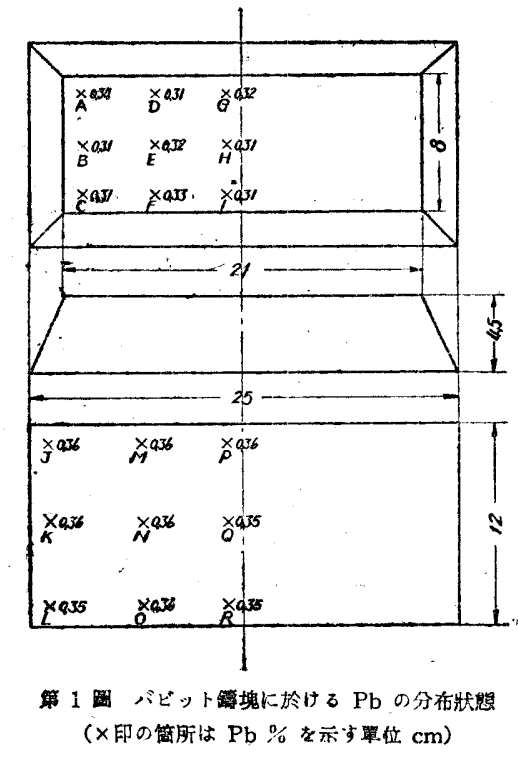
壵

\section{照}

\begin{tabular}{c|c|c|c|c|c|c}
$\mathrm{Ni}$ & $\mathrm{Pb}$ & $\mathrm{Sb}$ & $\mathrm{Si}$ & $\mathrm{Sn}$ & $\mathrm{Zn}$ \\
\hline- & - & - & ++ & +++ & - \\
- & ++++ & \pm & +++ & 5 & - \\
- & + & - & ++ & 10 & -
\end{tabular}

監化第一錫中 $\mathrm{Pb}$ 定监分光分济結果

\begin{tabular}{|c|c|c|c|}
\hline $\begin{array}{l}\mathrm{Pb} \pi \hat{~} \\
ク ト ル \text { 線 }\end{array}$ & 触度 & $\begin{array}{l}\mathrm{Pb} \text { ス八 } \\
\text { クトル縓 }\end{array}$ & 虽度 \\
\hline 4057.8 & - & 3639.6 & \\
\hline 3683.5 & + & 2802.0 & + \\
\hline 2833.1 & ++ & 2614.2 & + \\
\hline
\end{tabular}

第 11 表 バビット・メタルの分析結果

\begin{tabular}{|c|c|c|c|c|c|c|c|c|c|}
\hline 䔈驗回繁 & 1 & 2 & 3 & 4 & 5 & 6 & 7 & 8 & 平 \\
\hline 路 $(\%)$ & 0.26 & 0.28 & 0.27 & 0.28 & 0.28 & 0.26 & 0.27 & 0.27 & 0.27 \\
\hline
\end{tabular}

に依り、フンチホンは試料を硫酸に溶解し直らに過マンガン酸加 里にて滴定した．結果は第 2 圖の如くである.

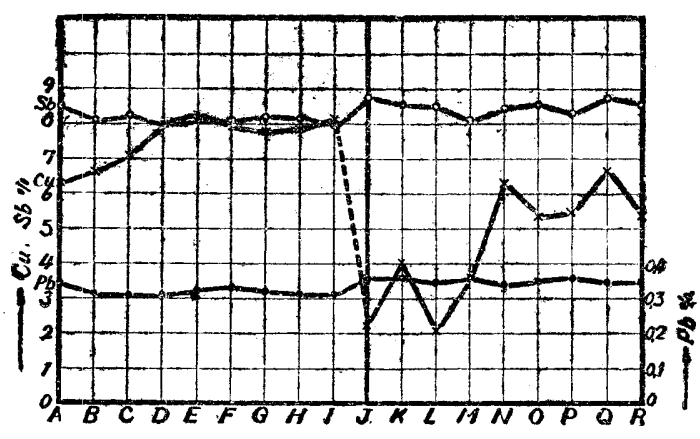

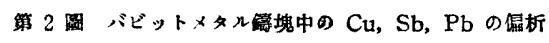

4. 結

（1）バビット・メタル中の少量の鍇の定量は熟練を姴せず，操 作簡易且汗速と云ふ點で電解法が宜しい。

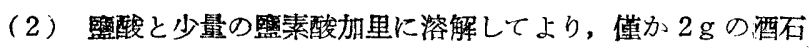
酸添加で分析し得る故に酒石酸が節約出來る.

（3）酒石酸中に鉛が相掌存在する場合があるから，か小る場合

には豫め水溶湤として電解により鉛を除去せねばならない，

（4）バビット鏢塊中に於いて $\mathrm{Pb}$ は早く冷却せる面に稍々多く 含有せられるが銅程大きい、偏析はない。

(昭和 19 年 4 月 17 日受理)

文献

(1) 村田·舴田: 化., 11 (1943) 139

(2) " " : "., 11 (1943) 361

\section{次亞監素酸と沃素イオンとの酸化還元反應に就いて}

\section{立 木 健 吉 (東北帝國大學理學部然機化學㸚空)}

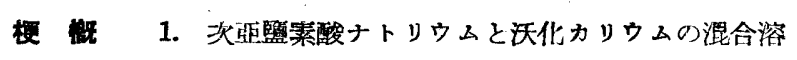
液に滴定的に硫酸を加一，其の溶液の $\mathrm{pH}$ を測定した結果，先; 次の反應加起り

$2 \mathrm{NaClO}+\mathrm{H}_{2} \mathrm{SO}_{4}=2 \mathrm{HClO}+\mathrm{Na}_{2} \mathrm{SO}_{4}$

次いで $\mathrm{HClO}$ は沃素イオンと反憵し

$\mathrm{HClO}+2 \mathrm{~J}^{-}+\mathrm{H}^{+}=\mathrm{Cl}^{-}+\mathrm{J}_{2}+\mathrm{H}_{2} \mathrm{O}$

が進む.而して此の反應は重曹溶液より $\mathrm{pH} の$ 高い場合でも若于 行はる〉も，其の反憵を完全に終了せしむる $\mathrm{pH}$ は 5 以下である ことを確めた。
2. 以上の反應を $\mathrm{pH}$ の異なる各種の綏衝溶波に於いて行はし

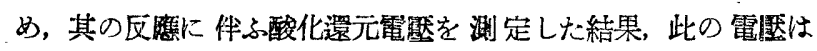
$\mathrm{pH}$ の變化に件ふ反睛進行率の如何に拘はらず，略同一值夌示 す. 反應が究全に進行した塨合の電厴は $\mathrm{J}_{3}{ }^{-}-3 \mathrm{~J}$ - 間の酸化澴元 電硻としてよく說明せられる.

3. 酸性又はアルカリ性の䜌衝溶液に於いて, 沃化カッウムに

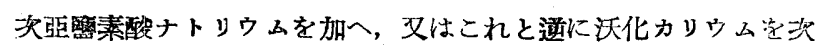

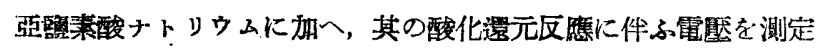
し, 反礁の段階に就いて檢討した。其の絬果重曹溶液に於いては 
$\mathrm{JO}_{3}$ 一生成の段階の久定量的に行はるつに反し，酸性溶液に於い ては(其の $\mathrm{pH}$ が 3.92 の如く相當低い場合には) $\mathrm{JO}_{3}$ - 生成の段 階のみならず, $\mathrm{J}_{2}, \mathrm{HJO}$ 生成の段階も亦大體定量的に行はるわこ とを認めた。

以上の如く笔氣化學的に溶液の $\mathrm{pH}$ と次監䜿素酸の反睢性に就 いて檢討した結果，pHの高くなるに從ひ，顯著に酸化力法減じ 又、酸化の速度子低下する．この傾向酸化還元電嚂に現れた傾向 と同樣である。

\section{1. 䋨 䈏}

著者は前報 ${ }^{(1)}$ に於いて次亞臨素酸イオン及び亞監素酸イオンの 酸化罯元電位を測定した，其の結果は何れのイオンに於いても理 馀值より遥かに低い、電位を與へた。特に亞監素酸イオンに於いて 其の低下の程度は甚しかつた.文其の溶液の $\mathrm{pH}$ 茼くなるに從つ て此の䉙位は益低下する.而して此の低下の主なる原因が其れ等 のイオンの與る電極反應がアルカリ性溶液では頗る緩慢で充分に 可逆反應を起し得ないことにある策を指摘した，又此の電㥛反鷹

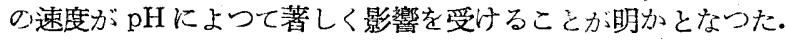
此の事は電極反雇のみならず他の反應に於いても當然起るべきで 女つて，實際に沃素イオンに對する酸化反應光見るに其の候问が

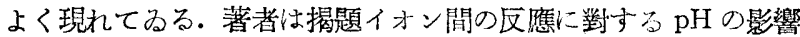
及心゙其の反㤫機構が $\mathrm{pH}$ によて如何に變るが酸化還元電位の 湘定から檢討した．次に是等に就いて報告する。

\section{2. 反鹰の難易と $\mathrm{pH}$ との關係 - pH 曲線による反鷹の檢討}

次亞鼠素酸乞沃素イオンとの反隹は多くの場合，水素イオンが 關與してるるので，反應溶液に濑次酸を加へて行き，其の $\mathrm{pH}$ を

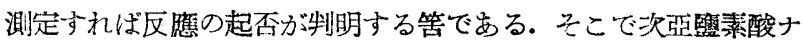
トリウムと沃化カリウムとの混合溶液に硫酸学滴定的に加へてて行 き $\mathrm{pH}$ 曲線を求めた。

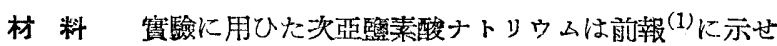
る如く，酸化水銀に監素を作用せしめて，次亞監素酸を製し，こ れに計算量の苛性曹達を加へて作つた。溶液の俵度は沃素法で定 せた．沃化カリウムは犬印保證付のものを用ひ，溶解した重量か ら溜度を定めた．硫酸は鹿印保登付を用ひた。

pH の測定 溶液か酸化性のため, 砣子䉓極を用ひ， $\mathrm{pH}$ を 測定した. $\mathrm{pH}$ の基準溶液には $0.1 N$ 醋醊醌酸曹達の䌊衝溶液を 用ひ，

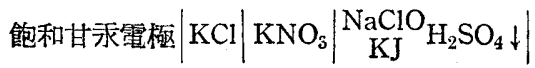

硝子 $\left|0.1 N_{\mathrm{NaAc}}^{\mathrm{HAc}}\right| \mathrm{KNO}_{3}|\mathrm{KCl}|$ 飽和甘承電極

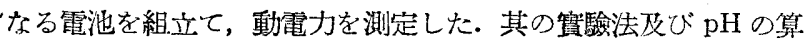
出法は既に前報 (2)に詳述した通りである.刨ち $\mathrm{pH}$ 㳄次式によつ て求めた。

$$
\mathrm{pH}=4.645-\frac{E}{0.05914}
$$

溶液の調製賣驗に用ひた溶液の組成は次の如きものでま る.

\begin{tabular}{|c|c|c|}
\hline$(\mathrm{NaClO}$ & $(0.10023 \mathrm{~N}, 19.92 \mathrm{cc})$ & $0.00799 N$ \\
\hline$\{\mathrm{KJ}$ & $(0.10008 \mathrm{~N}, 69.90 \mathrm{cc})$ & $0.02800 \mathrm{~N}$ \\
\hline （全谷 & $249.86 \mathrm{cc}$ & \\
\hline $\mathrm{H}_{2} \mathrm{SO}_{4}$ & $0.10044 N$ & \\
\hline
\end{tabular}

上記の如く次亞鼠素酸ナトリゥム 1 モルに對し，沃化カリウム 7 モル(規定にて 3.5 倍)を加へた。これは測宝中に析出する沃素
を $\mathrm{J}_{3}$-として溶液內に保たしめるためである．硫酸の添加は 10 min 間隔に行つた. 以上の如くして行つた實驗の結果は第1表に 示した.

第 1 表 次亞監溸酸ナトリウム及び沃化カリウムの温 合溶液に硫酸を滴トした場合の $\mathrm{pH}$

\begin{tabular}{|c|c|c|c|c|c|c|c|}
\hline 時䦓 & $\begin{array}{l}\text { 硫酸漂加量 } \\
\text { (cc) }\end{array}$ & 動鼠力 & $\mathrm{pH}$ & 蒔間 & $\begin{array}{l}\text { 酼酸潦加量 } \\
\text { (cc) }\end{array}$ & 動 電 力 & $\mathrm{pH}$ \\
\hline 5 & 0.5 & 0.39187 & 11,292 & 84 & 20.0 & 0.0304 & 5,180 \\
\hline 11 & 2.0 & 0.38617 & 11,195 & 90 & 21.0 & 00227 & 5,050 \\
\hline 17 & 4.0 & 0.37728 & 11,045 & 96 & 22.0 & 0.0279 & 5,148 \\
\hline 23 & 6.0 & 0.36490 & 10,836 & 102 & 23.0 & 0.0235 & 5,063 \\
\hline 29 & 8.0 & 0.35262 & 10,628 & 108 & 24.0 & 0.0220 & 5,088 \\
\hline 35 & 10.0 & 0.33517 & 10,333 & 114 & 26.0 & 0.0098 & 4,892 \\
\hline 41 & 12.0 & 0.31526 & 9,996 & 120 & 28.0 & 0.0045 & 4,658 \\
\hline 47 & 14.0 & 0.28285 & 9,448 & 126 & 30.0 & 00468 & 3,875 \\
\hline 53 & 15.0 & 0.24500 & 8,808 & 132 & 31.0 & 00719 & 3,451 \\
\hline 59 & 16.0 & 0.15420 & 7,273 & 138 & 33.0 & 00930 & 3,093 \\
\hline 66 & 17.0 & 0.10587 & 6,456 & 144 & 35.0 & 0.10415 & 2,995 \\
\hline 72 & 18.0 & 007774 & 5,980 & 150 & 37.0 & 0.11038 & 2,800 \\
\hline 78 & 19.0 & 0.04979 & 5,508 & 156 & 39.0 & 0.11530 & 2,717 \\
\hline
\end{tabular}

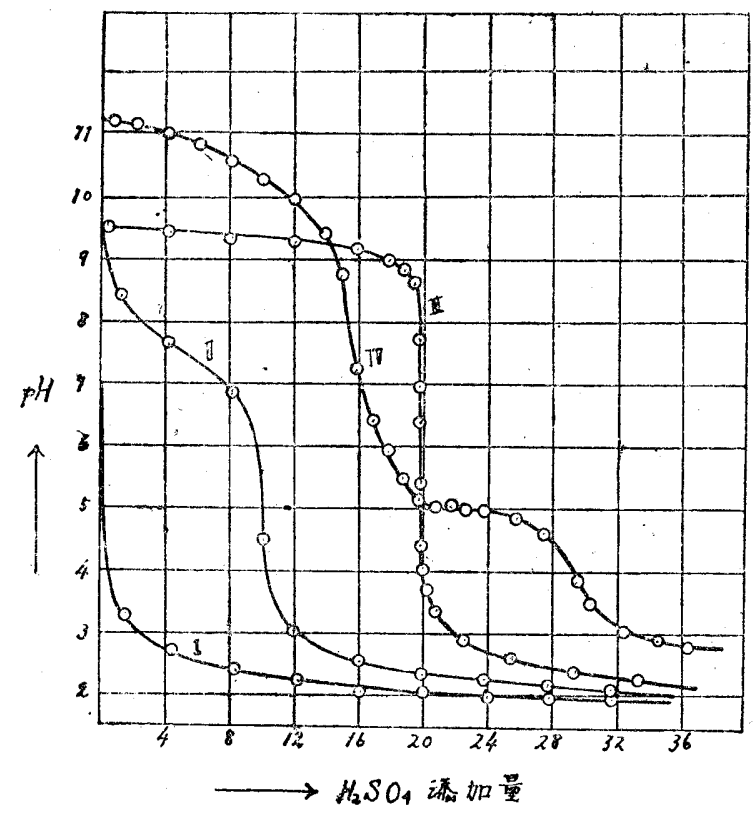

第 1 图 次亞監莱酸ナトリウム及び沃化カリウム混合溶渡 に於いて硫酸添加に体心 $\mathrm{pH}$ の戀化

これを圆に示すと第I圖の曲線 IV の如くになる．同圖に於い て曲楾Iは訫算によつて求めたもので曲線 IV と同容積の水に硫 酸を同じ樣に加一て行つた場合のpH の曲線である. 曲線 II も亦 計算によつて求めたもので曲線 IV と同漂度の次亞擥素酸ナトリ ウムに碳酸を同じ樣に加へて行つた場合の $\mathrm{pH}$ 曲線である. 此の 場合，硫酸は次亞留素酸ナトリウムに作用し，次亞監素酸を生ずる.

$2 \mathrm{NaClO}+\mathrm{H}_{2} \mathrm{SO}_{4}=\mathrm{Na}_{2} \mathrm{SO}_{4}+2 \mathrm{HClO}$

次亞監素酸は笔離恒數が $3 \times 10^{-8}$ であるから反應は殆ど右に進

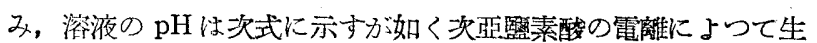
ずる水素イオン㨱度によつて卖配される。

$$
\mathrm{HClO} \rightleftarrows \mathrm{H}^{+}+\mathrm{ClO}^{-}
$$

從つて曲線に示さる〉樣に (1) の反隹が終つて過剩の硫酸が溶 液に殘るまでは $\mathrm{pH}$ は餘り低下しない。郎ち一種の中和反隹をな してみる.此の㭙の水素イオン濃度は次の如くにして求めた。 


$$
\left[\mathrm{H}^{+}\right]=2 b a
$$

但 $L a$ は

$$
\frac{2 b a(a-2 b+2 b a)}{2 b(1-a)}=3 \times 10^{-8}
$$

に上り求む.

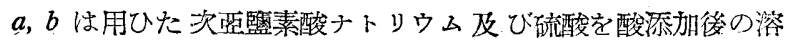
液に於ける濃度として表した量， $a$ は次亞監素酸の電離度であ る.

曲線 III は本測定に於いて潮次滴加した硫酸が次に示寸柱な反 應に完全に消費されたと假定した時の溶液の $\mathrm{pH}$ 曲線である。

$\mathrm{NaClO}+2 \mathrm{KJ}+\mathrm{H}_{2} \mathrm{SO}_{4}=\mathrm{NaCl}+\mathrm{K}_{2} \mathrm{SO}_{4}+\mathrm{J}_{2} \ldots$

これは溶液の $\mathrm{pH}$ が末反應の次亞監素酸ナトリウムが存在する 間はこのるのの加水分解によつて结ずる水酸イオンの濃度によつ て定まると考へて次の如計算によつて求めたるのである。

$\mathrm{ClO}^{-}+\mathrm{H}_{2} \mathrm{O} \rightleftarrows \mathrm{HClO}+\mathrm{OH}^{-}$

$K_{h}=\frac{C a^{2}}{1-a}$

$\therefore \quad\left[\mathrm{OH}^{-}\right]=C a=\frac{-K_{h}+\sqrt{K_{h}^{2}+4 C K_{h}}}{2}$

$K_{h}$ は加水分解恒數にして， $K_{h}=\frac{1}{3} \times 10^{-6}$ を思ひた. 斯くの如 く加へた碳酸が完全に反應にあづかる埸合を考へると，pH の變 化は極めて僅かである. 然し反應終了後は加へた硫酸はそのま〉 残つて行くので $\mathrm{pH}$ は急激に低下する。

次に以上の曲線 I, II, III を基にして實湘の曲線 IV を考察す

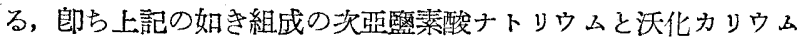
の混合溶液に硫酸を滴定的に加一て行く特始めの中は $\mathrm{pH}$ の举化 が可なり緩慢である。これは曲線 II の如く加へを硫酸が先づ沃 亞監素酸ナトリウムに作用し，(1) 式の如く，次亞監素酸を生ず るためと考へられる。

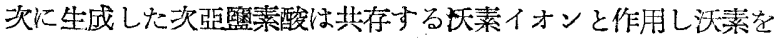
遊離し $\mathrm{J}_{3}$-を生ずる.

$$
\mathrm{HClO}+3 \mathrm{~J}^{-}=\mathrm{J}_{3}{ }^{-}+\mathrm{Cl}^{-}+\mathrm{OH}^{-}
$$

此の場合溶液は緩衝溶液ではないから水素イオンの補給が行は れず反應は(5)式で停止し，溶液はアルカリ性となる. 從つて(3) 式の如く反磼が完全に終了すると考へた㭙の $\mathrm{pH}$ に比較して實際 の $\mathrm{pH}$ が遥かに高いのも此の篇と考へられる.（實湘の $\mathrm{pH}$ は 11.25 を示してるるが, これは硝子電極のアルカリ誤差のため若 干高過ぎて出てるるので筫際の $\mathrm{pH}$ はこれに補正を加へなければ ならない.)叉, 此際沃素イオンが次亞沃素酸イォン又は沃菜酸イ オンに酸化される反應は勿論せり得るが溶液中心沃素イオンが過 剩にあるので, 假に生成しても值ちに沃素に還元される故, 此際 は考へる必要はない。

次いで漸次硫酸を加へて行くときは，曲線 II に示すが如く (1) の反應が終了するに至れば, (此の時の酸の所要量は $9.94 \mathrm{cc}$ ) 加へ た酸は(5)式の反隹によつて生ずる水酸イオンを中和して浴液の pH は曲線 II に近く低下すべきで女るが，璸際には

$$
\mathrm{HClO}+2 \mathrm{~J}^{-}+\mathrm{H}^{+}=\mathrm{J}_{2}+\mathrm{Cl}^{-}+\mathrm{H}_{2} \mathrm{O}
$$

なる反應が可成り進行してるるので，相當に酸定加へなければ $\mathrm{pH}$ は低下しない. 然しながら加へた酸が完全に反雇にあづかつ てるるのでないこと曲線 III と此較して見る時明膫である。毁 ち曲線 IVに於いては末反應の水素イ゙オンが相當に殘つてるるの で $\mathrm{pH}$ は曲線 III より遥かに早く降下する。然し其の間，反㗹は
漸次淮み pH 5.17 で曲線 III, IV、は交る. 此の艾默は水素イォ ン側から見た反應終了點に相虽するので此の $\mathrm{pH}$ 以下なれは反礁 は完奎に終了するものと見ることが出來る．然る眭は此の艾點以 下では曲線 III, IV は互に近づいて居らなければならないが實際 には此の交墨以下に於いて尚可成りの開きが安る。これは此の兴 點に於いて未だ相篦の次亞䜿素酸が殘留してるるため，これが沃 素イオンと急速に反應し，此の反應終るまで $\mathrm{pH}$ が餘り變化しな いのではないかと思はれる。

\section{3. 不應の機構並に反應察と $\mathbf{p H}$ 一一電瑿曲線による反應の檢討}

前節の實驗により水素イオンの與る反應が如何なる $\mathrm{pH}$ に於い て起的易导かを明かにした，そこで其の水素イオンの與る反應芯

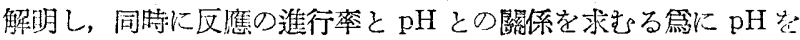

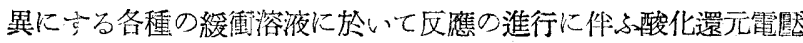

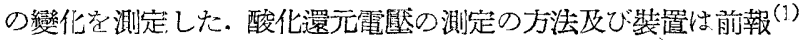
に報告したものと同一でする。而して使用した電池は次の如き方 のである。

$\Theta \mathrm{Hg}|\mathrm{HgCl}(\mathrm{S})| \mathrm{KCl}$ (飽和) $|\mathrm{KCl}| \mathrm{KNO}_{3} \mid \mathrm{KJ}$ (緩衝溶液) $+\mathrm{NaClO} P \mathrm{Pt} \oplus$

唯晎なる所は $\mathrm{KNO}_{3}$ の監橋を $\mathrm{KCl}$ の鹽橋の次に連絡し，且つ 監橋の先端を摺合せとなし，長時間の湘定中に於ける溶液の混交

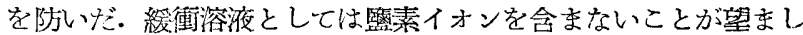
いのて, $\mathrm{pH}$ が 3〜5の間は醋酸一醋酸曹達混合浚液，6〜8の閐 は第一粼酸加里一菏性曹澾の混合溶液を使用した。電昀の測定に 先立つて先づ亩記の緩衝鉴液に沃化カリウムの浴液を加へて, 此 の $\mathrm{pH}$ を測つて置く，次いで, 此の溶液を白金極容器に入れ，留 池を組立て，30 mir 万至 $1 \mathrm{hr}$ 放置する.斯ぐして白金極の電䛗

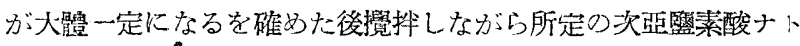

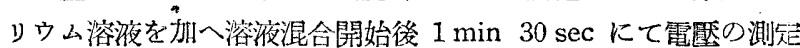
を始奴，測定結果は第 2 表及び第 2 圖に示した。最終の電距

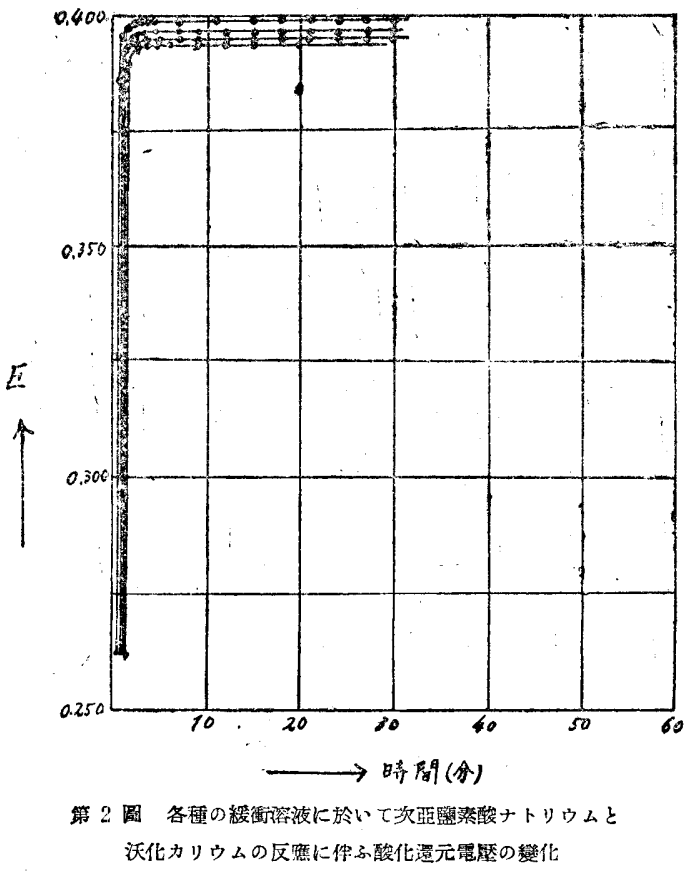

を水素電極を基準に換算した結果 $E_{h}$ は夫々の欄の終りに記し た. 此の結果を見るに $\mathrm{pH}$ の如何に拘らず電堅は急速に上昇し, 


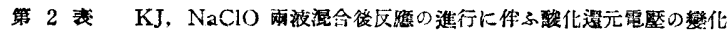

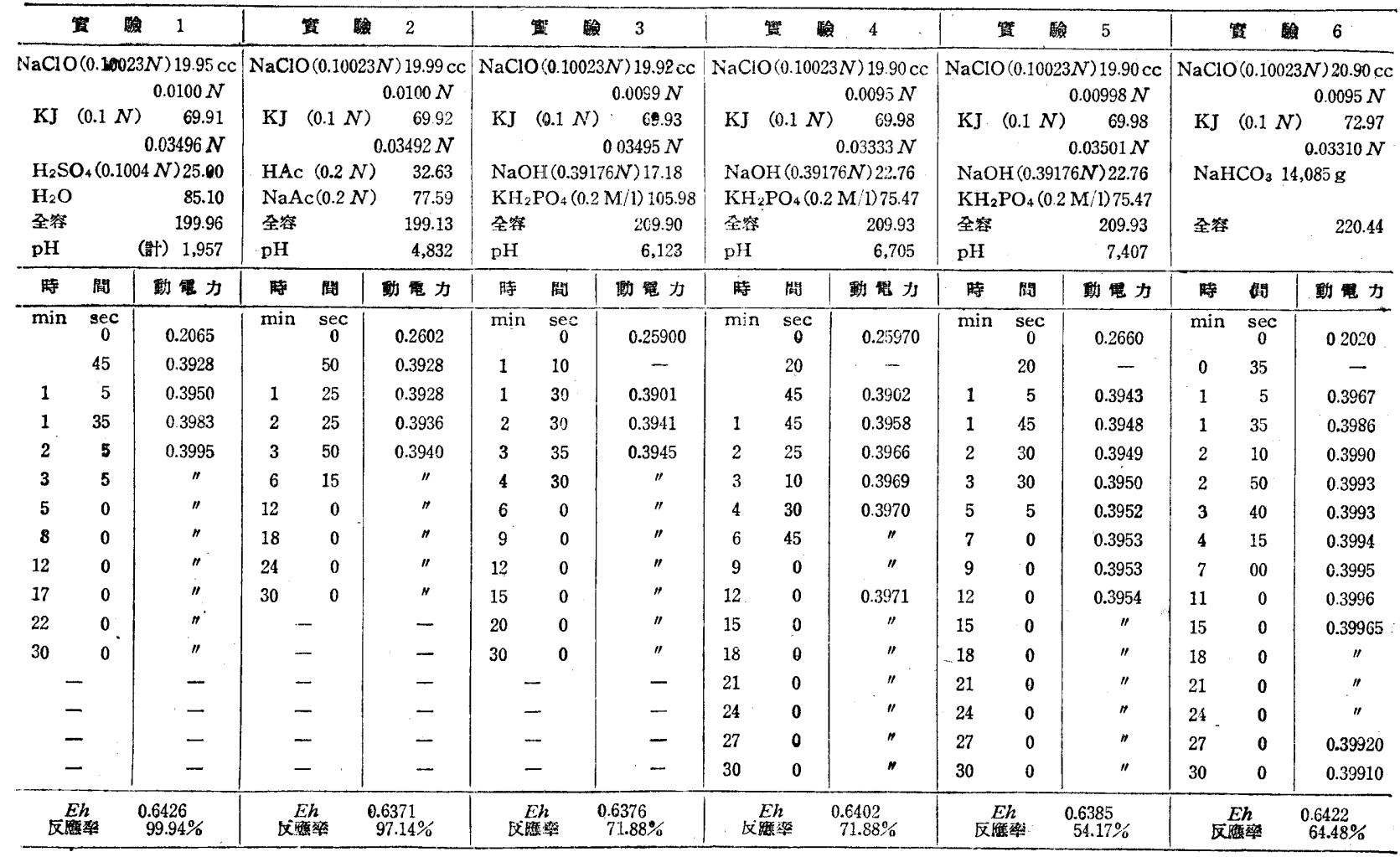

且つ $0.395 \mathrm{~V}\left(E_{h}=0.638 \mathrm{~V}\right)$ 前後の一定電厴に落ちついてるる. にれは凡て反應の完結を推定せしめたが測定役の浫液に就いて析 計せる沃䒧をチオ硫酸曾澾の溶液にて滴定した結果，第 2 表に於 ける夫ふの欄の終りに示如く $\mathrm{pH}$ に传つて反應の進行度に著し い差を示した。これを畐に示すと第 3 圖の曲線の如くになる.こ

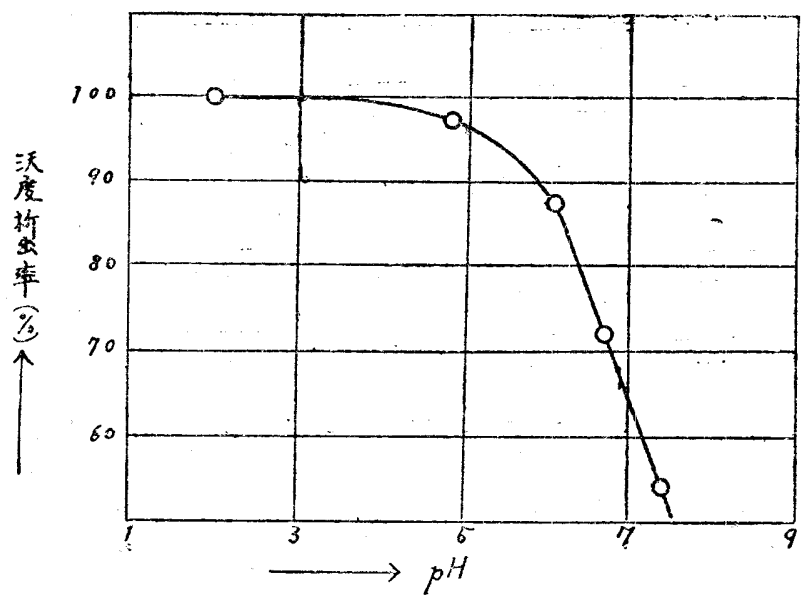

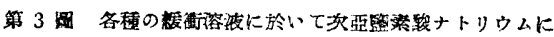

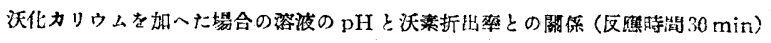

れによつて見れば区應の終了には少くとも $\mathrm{pH}$ む゙必要である.これ恃第 2 節に示した惯驗結果と一致した。然る 時は妶に得た酸化還元電位は如何なる反磼に基いて發生せるもの 名考察を加へて見る.

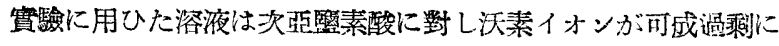
入つてるるのであるから

$\mathrm{HClO}+3 \mathrm{~J}^{-}+\mathrm{H}^{+}=\mathrm{J}_{3}{ }^{-}+\mathrm{Cl}^{-}+\mathrm{H}_{2} \mathrm{O}$
なる反隹が起つてるるものと見做される．然るに賽驗によつて得

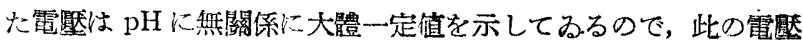
は水素イオン心與らない反隹に基いてるると見ねばならない。然 る特は此の條件を滿足すると共に笔壓の大さから見て

$$
J_{3}{ }^{-}+2 e^{-}=3 J^{-} \quad E_{0}=0.5355 .
$$

(8)式炕示与が如き $\mathrm{J}^{-}-\mathrm{J}_{3}$ - 間の酸化還元反應が最も考へられ易 いのであるが，筫測の電堅は沃素の析出率如何に拘らず一定とな つてるる. 從ひて斯かる酸化還元反碓は(7)式の反應が完全に進 行した場合を除いて其の屯〉適用することは困難である. (7)式が 芫全化進行した場合, 溶液の電竪が $\mathrm{J}^{-}-\mathrm{J}_{3}$ - 間の酸化還元反應 に基くとして其の標準䉓位を求めると $0.5554 \mathrm{~V}$ となる。これは 上記长示した $E_{0}$ に近い值である. 反應不完全の場合に對する以 上の鼠虚の解釋儿對しては更に研究に俟にねばならない。

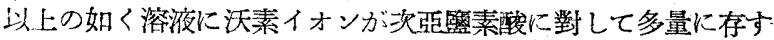
場合は (7)式の反應が起る。然しなが此の反應は電㗨曲線の示 す如く $\mathrm{pH}$ の凡ての範图に亘つて完全に進行するものでなく，第 3 画に示士樣に $\mathrm{pH}$ により两威の影響を受けるるのである。

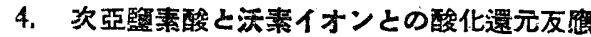

前節に於いては $\mathrm{pH}$ を一定に保ら次瑟監素酸と沃素イオンの各

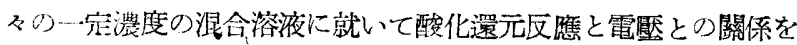
檢し心。本節に於いては酸性又はアルカリ性綏衝溶液に於いてて沃 美イオンに滴定的に次亞監素酸ナトリウムの溶液を加へた場合， 及ざこれと逆に次亞監素酸に沃素イオンを滴定的に加へた場合， 反潐の進行に件ふ酸化還元電算の戀化を测定し，反應の推移に就 いて确究した。是等の電㻺は大體に於いて一定値に達した值であ るが，これに餘りに時閒のかつるものは一定時間で打切り電壓を 定めた。

（1）重曾溶液に於ける反䔡 （A）沃化カリウムの溶腹に 


\section{次亞監慗酸ナトリウムの溶液を加へて行く場合}

實験に用ひた溶液

\begin{tabular}{|c|c|}
\hline \multicolumn{2}{|c|}{$0.005568 N$} \\
\hline $\mathrm{NaHCO}_{3}$ & $13.4412 \mathrm{~g}$ \\
\hline (全容量 & $180 \mathrm{cc}$ \\
\hline
\end{tabular}

實驗結果は煩雜に互るから數值を揭げることを略し（以下の富 驗結果も同樣) 第 4 圖の曲線 I K示した. 圖の縱軸には酸化還元 電堅を，橫軸には加へた次互監素酸ナトリウムの cc 数を示した。

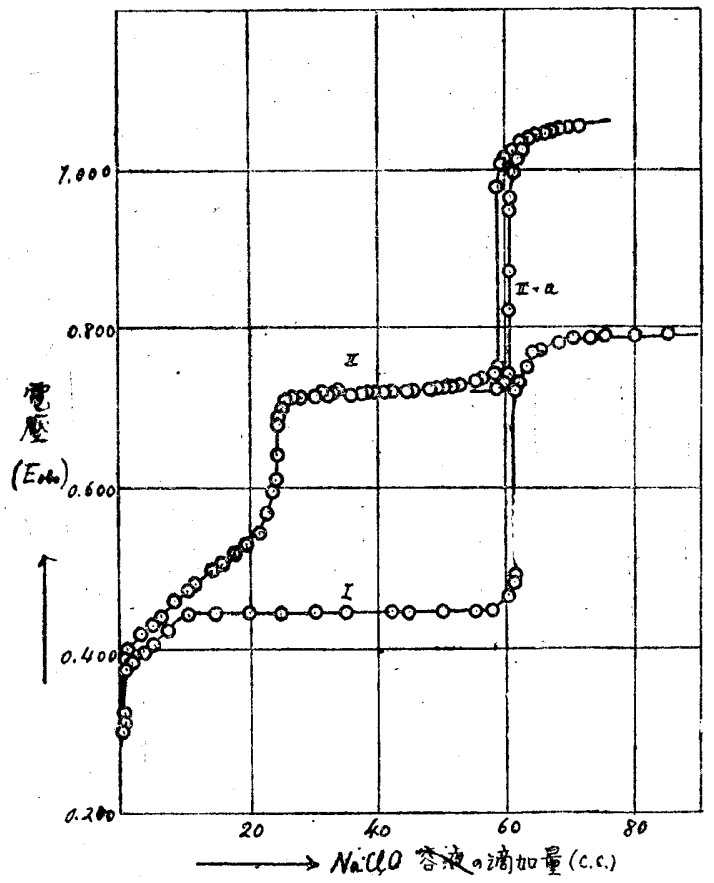

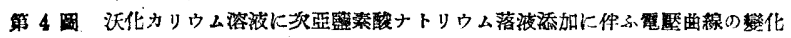

沃化カリウムの重曹浴液に次亞監素酸ナトリウムを加一る時は, その添加の量に比例して電堅加值線的に上昇し，炏いで一定値に 達する. その屈曲點 $10.00 \mathrm{cc}$ は沃素イオン 1 モルに對し次亞甈 素酸イオン $\frac{1}{2}$ モルに相當するので，(理論値 $10.12 \mathrm{cc}$ に對し惯 驗值 $10.00 \mathrm{cc}$ )

$$
2 \mathrm{~J}^{-}+\mathrm{HClO}+\mathrm{H}^{+}=\mathrm{J}_{2}+\mathrm{Cl}^{-}+\mathrm{H}_{2} \mathrm{O}
$$

なる反憵の終了する點と一致する.これから洘へて此の䉓堅の上

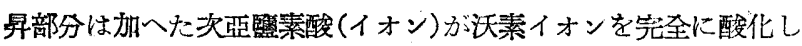
溶液には沃素と珁素イオンの久が存在するのではないかと云ふ事 が先づ考へられる. 然る時は此の閒の電穊は明かに沃素イオンと $\mathrm{J}_{3}$ - 文沃沃素 $\left(\mathrm{J}_{2}\right)$ との間の酸化還元電位を示してるるものと見ね ばならない。

そこで此の範園の測定做に就いて加へた次亞䣺素酸イオンが完 全に消費されたとして，管測の酸化還元電位と $\log \frac{\left[\mathrm{J}^{-}\right]^{3}}{\left[\mathrm{~J}_{3}-\right]}$ の關係 を求めると玨論的の關係を滿足しないのみならず，假りに(8)式 が適用さるるとして求め大標蕉電位 $0.501 \mathrm{~V}$ は從來の値 $0.5355 \mathrm{~V}$

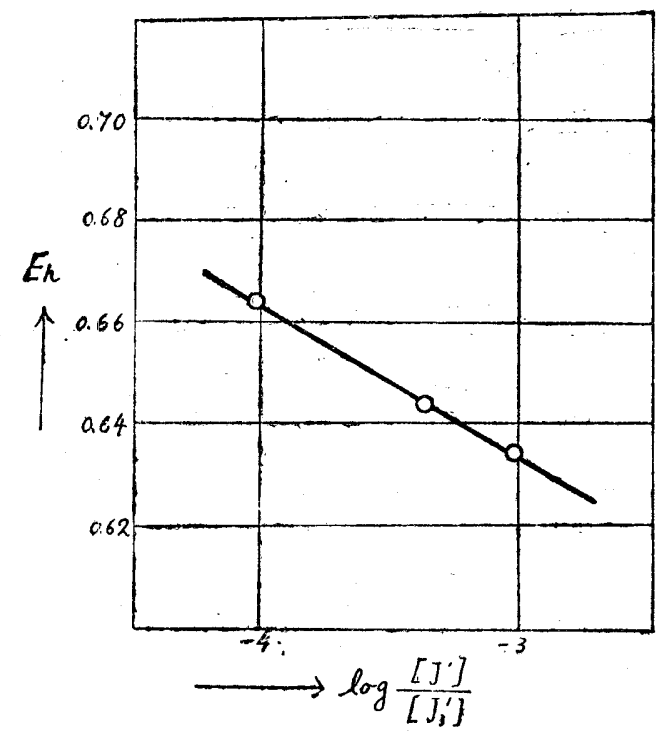

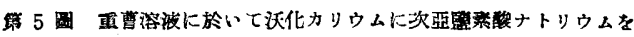

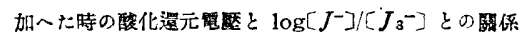

に比して低過ぎる.從つて (9)式の反應が完全に絡了したと考 るの以妥當でない，依つて第3節の實驗に示した樣に，電烈は区

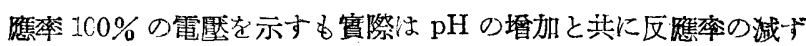
ると云ふ事を考慮に入れて，重曾溶液の反應率を前算の結果に甚 き $51.29 \%$ として計算する特は, $\log \left[\mathrm{J}^{-}\right]^{3} /\left[\mathrm{J}_{3}{ }^{-}\right]$泩第 3 表に示与 が如くになる。これと䉓涯との關係を求めると第 4 圖に示すが如 く值線關係を得. 且つこれが $\log \left[\mathrm{J}^{-}\right]^{3} /\left[\mathrm{J}_{3}-\mathrm{C}\right.$ 軸との傾斜は 0.029 にして,よく理論值 0.0296 と一政する.依つて (8)式の反㗹に基

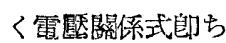

$$
E_{h}=E_{0}-0.0296 \log \frac{\left[\mathrm{J}^{-}\right]^{3}}{\left[\mathrm{~J}_{3}^{-}\right]}
$$

より $E_{0}$ を求めると第 3 表の第10行に示すが如き值を得る。これ は從來の值に可なり近い值である，從つて重曹溶液に於ける(9) の反㕍は電㗨曲線の上では終了するが如きも筫際は第 3 篩の第 3

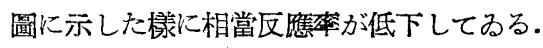

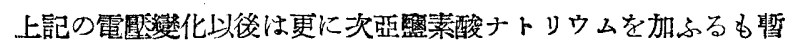

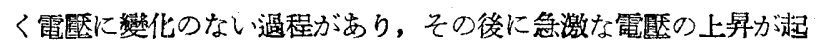
る. 此の默沃沃素イオン 1 モルに對し, 次亞䜿溸酸 3 モルの割合 (理論値 $60.75 \mathrm{cc}$ に對し, 實驗值 $60.7 \mathrm{cc}$ ) に相當するので

$$
J_{2}+5 \mathrm{ClO}^{-}+2 \mathrm{OH}^{-}=2 \mathrm{JO}_{3}{ }^{-}+5 \mathrm{Cl}^{-}+\mathrm{H}_{2} \mathrm{O} \text {. }
$$

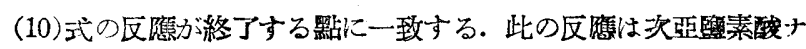
トリウムの所要量が理諭值に極めてよく一致することから見て腚 量的に行はる、反鷹であるが，可なり緩慢な反應である．而して 此の間電鍳に殆ど變化のないのは次の如き反應力起るためと考い られる。

$$
\begin{aligned}
& \mathrm{J}_{2}+\mathrm{ClO}^{-}+2 \mathrm{OH}^{-}=2 \mathrm{JO}^{-}+\mathrm{Cl}^{-}+\mathrm{H}_{2} \mathrm{O} \\
& \mathrm{JO}^{-}+2 \mathrm{ClO}^{-}=\mathrm{JO}_{3}-+2 \mathrm{Cl}^{-} \ldots \ldots \ldots \ldots \ldots \ldots
\end{aligned}
$$

\begin{tabular}{|c|c|c|c|c|c|c|c|c|c|}
\hline 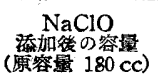 & 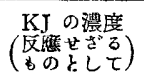 & 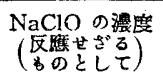 & 反 䨐 & $\mathrm{J}_{3}-$ の潎度 & 未反嶏の $\mathbf{J}^{-}$ & $\cdot \log \frac{\left[J^{-}\right]^{8}}{\left[J_{3}-\right]}$ & $E_{o b s}$ & $E_{h}$ & $E^{\bullet}$ \\
\hline 181 & 0.005801 & $0.0^{3} 5498$ & $51.29 \%$ & $0.0^{3} 1410$ & $0.0^{2} 5057$ & --3.0328 & 0.3914 & 0.6345 & 0.5448 \\
\hline 182 & 0.005769 & $0.0^{2} 1093_{6}$ & $"$ & $0.0^{3} 2805$ & $0.0^{2} 4929$ & --3.3699 & 0.4005 & 0.6436 & 0.5436 \\
\hline 185 & 0.005676 & $0.0^{2} 2689_{7}$ & $"$ & $0.0^{3} 6897$ & $0.0^{2} 3606$ & --4.1675 & 0.4214 & 0.6645 & 0.5408 \\
\hline
\end{tabular}

郎ら沃素が一度次亞沃素酸イオンに酸化せられるがこれは更

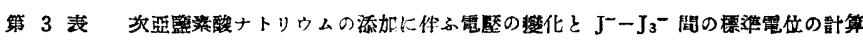


に沃素酸に酸化せられる. 從つて次弶沃素酸イォン性生成されて む中間狀態として存在する丈であるから曲線上折點として現はれ

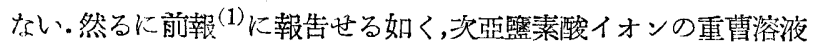
に於ける酸化還元電位の測定に於いて現れた電厴は, $\mathrm{ClO}^{-}$が次 式に示すが如き不可逆反應に基くものなることか明かとなつた。

$$
2 \mathrm{ClO}^{-} \longrightarrow 2 \mathrm{Cl}^{-}+\mathrm{O}_{2} \text {. }
$$

從つて(11)式に示された沃素の酸化は次亞䁃素酸イオンの不可 遡分解によつて出來た酸素により行はれると見做すことが出來 引.

$$
\mathrm{J}_{2}+\mathrm{O}_{2}+2 \mathrm{e}^{-} \longrightarrow 2 \mathrm{JO}^{-}
$$

然る時は實際測定された電算は

$$
E_{h}=E_{0}-\frac{R T}{2 f} \ln \frac{\left[\mathrm{JO}^{-}\right]^{2}}{\left[\mathrm{~J}_{2}\right]\left[\mathrm{O}_{2}\right]}
$$

こっに $\left[\mathrm{O}_{2}\right]$ は前報に示せる如く

$\left[\mathrm{O}_{2}\right]=x\left[\mathrm{ClO}^{-}\right]^{2}$

そ置くことが出來る故

$$
E_{h}=E_{0}-\frac{R T}{2 f} \ln \frac{\left[\mathrm{JO}^{-}\right]^{2}}{x\left[\mathrm{~J}_{2}\right]\left[\mathrm{ClO}^{-}\right]^{2}}
$$

本式に於いて JO- は中間的に存在するものであるから，一旦 は生成されても $\mathrm{ClO}^{-}$と平行して減少する.

即古 $\left[\mathrm{JO}^{-}\right]=k\left(\mathrm{ClO}^{-}\right]$

故に(13)式は

$$
E_{h}=E_{0}-\frac{R T}{2 f} \ln \frac{k^{2}}{\left.x \llbracket \mathrm{J}_{2}\right]}
$$

然るに沃素は溶解度が小でこの場合可なりの範圄に亘つて飽和 と見ることが出來る故 $\left[J_{2}\right]$ は一定で從つて $E_{h}$ は一定でなければ

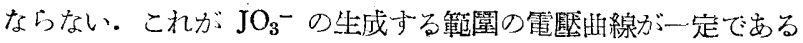
理由である.

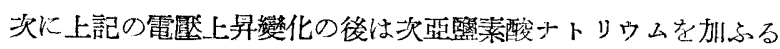

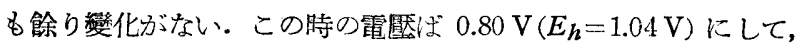

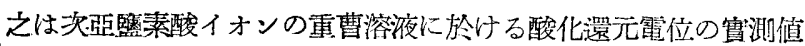
に近い.

（B）次亞䁂素酸ナトリウムの溶液に沃化カリウムの溶液を加

\section{人て行く場合}

實踰に用した溶液

$\begin{cases}\mathrm{NaClO}(0.10023 \mathrm{~N}, & 19.95 \mathrm{cc}) 0.015387 \mathrm{~N} \\ \mathrm{NaHCO}_{3} & 13.4412 \mathrm{~g} \\ \text { 全容量 } & 119.95 \mathrm{cc}\end{cases}$

$\mathrm{KJ}(0.1000 N)$

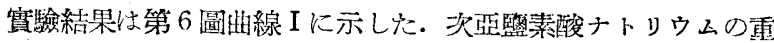
曹溶酸(この溶液の酸化還元電堅は $0.832 \mathrm{~V}\left(E_{h}=1.075 \mathrm{~V}\right)$ にして,

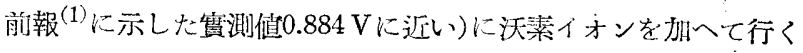

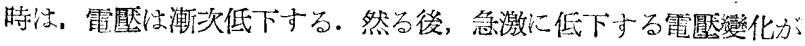

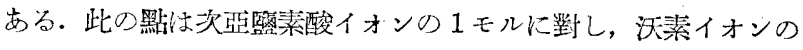
$1 / 3$ モルの割合（理論値 $3.33 \mathrm{cc}$ に對し，質驗值 $3.29 \mathrm{cc}$ ) に相當 するので

$3 \mathrm{ClO}^{-}+\mathrm{J}^{-}=3 \mathrm{Cl}^{-}+\mathrm{JO}_{3}^{-}$

なる反應の終了點と見做すことが出來る.此の反應の過程に於い てな次亞監菜酸イオンが多量にあるので, 加へ、沃菜イオンが中

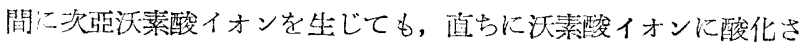
れることは明かでせる。爻沃素イオンを加へ火直後，沃素の着

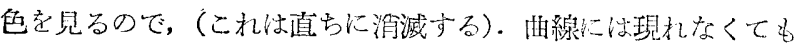
第 1 段階として $\mathrm{J}^{-} \rightarrow \mathrm{J}$, 第 2 段階として $\mathrm{J} \rightarrow \mathrm{JO}^{-}$，第 3 段階と乙

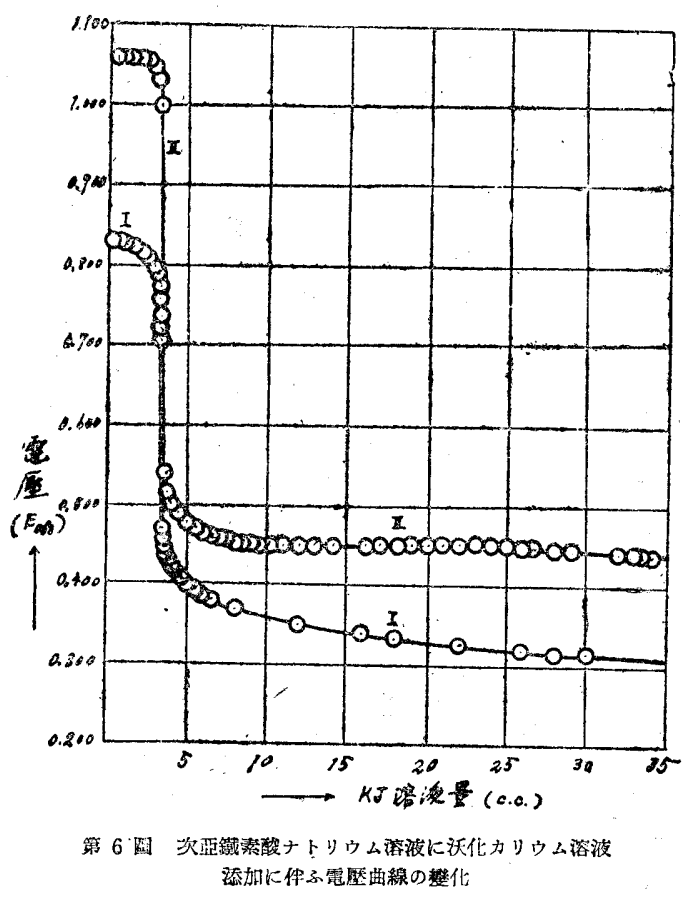

て $\mathrm{JO}^{-} \rightarrow \mathrm{JO}_{3}-$ の反應經過を巡るものと見るのが至當でせらう。

妶に注目すべきことは, 次亞監素酸イオンに沃素イオンを加 た場合は, この逆の沃素イオンに次亞監素酸イオンを加へた場合 に比して沃素イオンが沃素酸イオンに酸化される速さが大きい。 これ机前者に於いては，第 1 ，第 2 段階の經過特間が嫩めて短い. 长女已思礼る。

次に此の點以後は電堅は漸隇するの夕と，特別の變化は曲線の 上に现れて居らない，然し溶液の着色から，次の反應法起つてる るものと思はれる。

$\mathrm{JO}_{\hat{3}}^{-}+5 \mathrm{~J}^{-}+6 \mathrm{H}^{+}=3 \mathrm{~J}_{2}+3 \mathrm{H}_{2} \mathrm{O}$.

此の反應の終了點は此の明線上に示されて居らない。

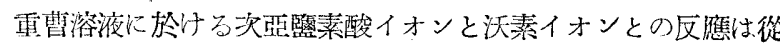
來から Pointius の反臀と呼ばれ，分析上にも應用せられてるる。 耳曹渗液の如く, $\mathrm{pH}$ が 8 以上の漫液に於ける滴定の終默に於い て沃素が析出する反應が起ることに對し，Kolthoff ${ }^{(3)}$ 活次の如く

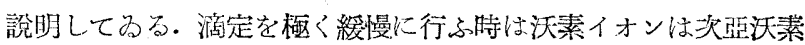
酸を經て沃素酸イおンに愁く酸化せられ，次いで

$$
\mathrm{JO}_{3}{ }^{-+}+5 \mathrm{~J}^{-}+6 \mathrm{H}^{+}=3 \mathrm{~J}_{2}+3 \mathrm{H}_{2} \mathrm{O}
$$

の反應に依り沃䕀が析出寸るも，缶速に行子特は，Bray ${ }^{(4)}$ の說 を引用し

$$
\mathrm{J}^{-}+\mathrm{ClO}^{-}+\mathrm{H}^{+}=\mathrm{JO}^{-}+\mathrm{Cl}^{-}+\mathrm{H}^{+}
$$

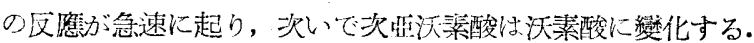

$3 \mathrm{JO}^{-}=\mathrm{JO}_{3}^{-}+2 \mathrm{~J}^{-}$

此反磼は緩慢に進むので，加へた沃素イォンは，沃亞沃素酸に 反應して沃素が析出步るとした。

$$
\mathrm{JO}^{-}+\mathrm{J}^{-}+2 \mathrm{H}^{+}=\mathrm{J}_{2}+\mathrm{H}_{2} \mathrm{O}
$$

渃し此の考へ厅方正しければ，重曹溶液に於いても酸性溶液と

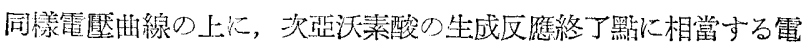

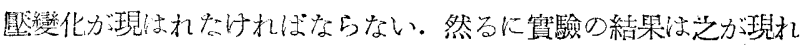

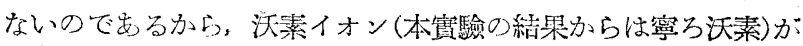

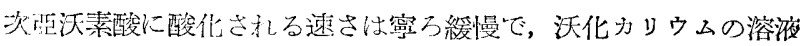

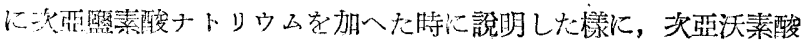


が沃素酸に酸化する速さ性，前者より早いものと見称ならない。

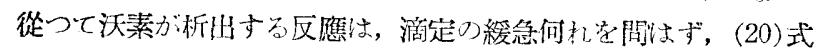

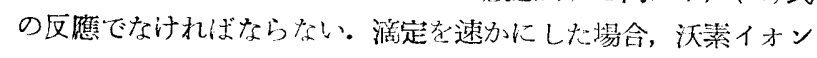

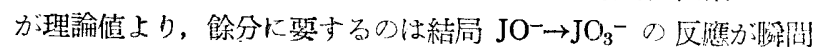
的に行はれない篇之見られる。

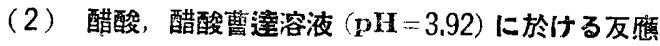
(A)

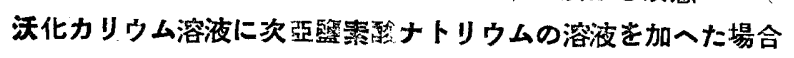
實驗に用ひた溶液

$\left\{\begin{array}{llll}\mathrm{KJ} & (0.1000 \mathrm{~N}, & 10.00 \mathrm{cc}) & 0.005272 \mathrm{~N} \\ \mathrm{HAc} & (0.20758 \mathrm{~N}, & 14.95 \mathrm{cc}) & 0.15534 \mathrm{~N} \\ \mathrm{NaAc} & (0.2 \mathrm{~N}, \quad 32.35 \mathrm{cc}) & 0.03411 \mathrm{~N} \\ \text { 全容量 } \quad 189.68 \mathrm{cc}\end{array}\right.$
$\mathrm{NaClO} \quad(0.098708 \mathrm{~N})$

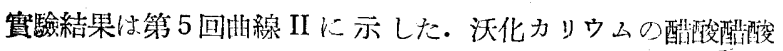
曹達溶液に次亞砶素酸ナトリウムの溶滩を加へて行く時は, 西崖

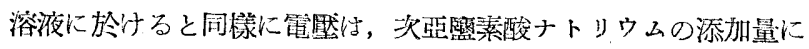
比例して直線的に上帠する.此間

$$
2 \mathrm{~J}^{-}+\mathrm{HClO}+\mathrm{H}^{+}=\mathrm{J}_{2}+\mathrm{Cl}^{-}+\mathrm{H}_{2} \mathrm{O}
$$

なる反應が進むものと見られるが，重皆溶液に於子るが如く，其 の反應終了黟に相當する屈曲點力明膫に現れてるない. 更に次亞

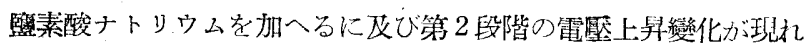

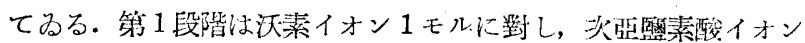
が 1 モルの割合(理論值 $20.16 \mathrm{cc}$ に對し，質驗値は $22.8 \mathrm{cc}$ )に相 當するので

$$
\mathrm{J}_{2}+\mathrm{HClO}+\mathrm{H}_{2} \mathrm{O}=2 \mathrm{HJO}+\mathrm{Cl}^{-}+\mathrm{H}^{+}
$$

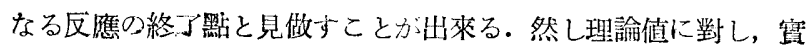
驗値が可なりずれ・とるる上に，沃素の色が完全に消減しない。之 は(24)式の反應がよく行はれず，理論值より餘分の次亞監素酸ナ

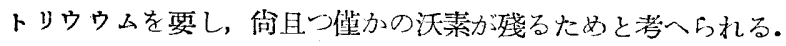

次に第 2 段階は, 沃素イオン 1 モルに對し, 炏亞䜿素酸イオン 3 モルの割合 (理論值 $60.34 \mathrm{cc}$ に對し, 實驗値 $58.40 \mathrm{cc}$ ) に相當 するので，次の反應の終了默と見做すことが出來る.

$\mathrm{HJO}+2 \mathrm{HClO}=\mathrm{JO}_{3}^{-}+2 \mathrm{Cl}^{-}+3 \mathrm{H}^{+}$

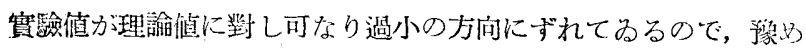
此の溶液に近い制合て混合し，再び此の點を测定した結果心明線

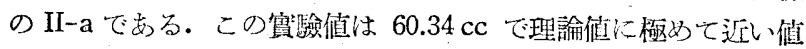
を得た. 從つて實驗值のずれてるるのは涀定時間の長いために途

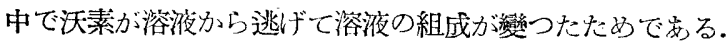

(B) 次亞覽素酸ナトリウムの溶液に沃化カリウムを加へた場 合

\begin{tabular}{|c|c|c|c|}
\hline $\mathrm{NaClO}$ & $(0.098708 \mathrm{~N}$ & $.20 .26 \mathrm{cc})$ & $0.015383 N$ \\
\hline $\mathrm{HAc}$ & $(0.20758 \mathrm{~N}$ & $86.70 \mathrm{cc})$ & $0.013844 N$ \\
\hline $\mathrm{NaAc}$ & $\langle 0.2 N$ & $19.75 \mathrm{cc})$ & $0.03038 \mathrm{~N}$ \\
\hline 容量 & $130 \mathrm{cc}$ & & \\
\hline $\mathrm{KJ}$ & $(0.1000 \mathrm{~N})$ & & \\
\hline
\end{tabular}

實騟に用ひた溶液

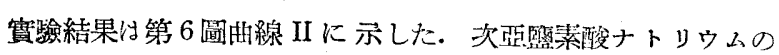

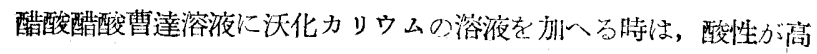
まつてるる篇に，電堅は總唱的に高くなつてるるが大䯣は重曹溶

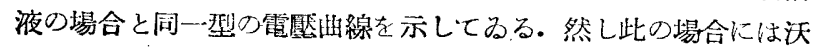

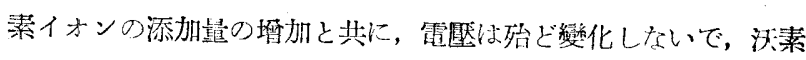

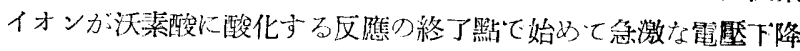
の變化がある。

$$
3 \mathrm{HClO}+\mathrm{J}^{-}=3 \mathrm{Cl}^{-}+\mathrm{H}^{+}+\mathrm{JO}_{3}^{-}
$$

此つ反應終了點は理論値 $3.38 \mathrm{cc}$ に對し, 貫驗値 $3.38 \mathrm{cc}$ を示

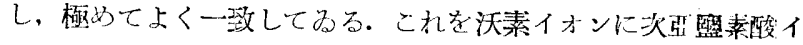
オン定加へて行く場合と比較するに，本筫驗に於、ては，沃菜或 は次恶沃素酸の生成が電歴仴線の上に現れてるない。これは次亞 篮素酸の量方沃素イオンに對して，過剩にあるので，これ等のも

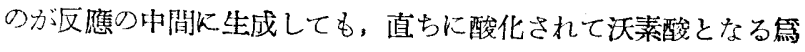
と思はれる。

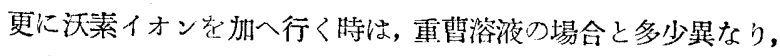

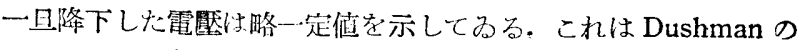

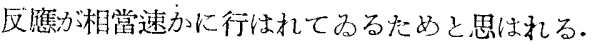

以上ナルカリ性或は酸性の緩衝浴液に於いて, 沃化カリウムに 次亞䈘素酸ナトリウムを加へて行く場合, 先づ重曹溶液にては

第 1 段階として $2 \mathrm{~J}^{-}+\mathrm{ClO}^{-}+2 \mathrm{H}^{+}=\mathrm{J}_{2}+\mathrm{Cl}^{-}+\mathrm{H}_{2} \mathrm{O}$

第 2 段階として $\mathrm{J}_{2}+\mathrm{ClO}_{-}^{-}+2 \mathrm{OH}^{-}=2 \mathrm{JO}^{-}+\mathrm{Cl}^{-}+\mathrm{H}_{2} \mathrm{O}$

第3 段階として $\mathrm{JO}^{-}+2 \mathrm{ClO}^{-}=\mathrm{JO}_{3}^{-}+2 \mathrm{Cl}^{-}$

上の順序にて J- を酸化して行く. 然し重曹溶液にては, JO-

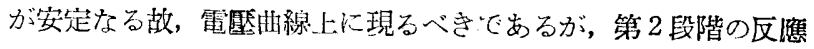
が遲いため, 生成したものが直ちに沃素”谷イオンに酸化され, 電 堅曲線の上に現はれない. 又酸性溶漼にては

第 1 段階として $2 \mathrm{~J}^{-}+\mathrm{HClO}+\mathrm{H}^{+}=\mathrm{J}_{2}+\mathrm{Cl}^{-}+\mathrm{H}_{2} \mathrm{O}$

第 2 段階として $\mathrm{J}_{2}+\mathrm{HClO}+\mathrm{H}_{2} \mathrm{O}=2 \mathrm{HJO}+2 \mathrm{Cl}^{-}+2 \mathrm{H}^{+}$

第 3 段階そして $\mathrm{HJO}+2 \mathrm{HClO}=\mathrm{JO}_{3}^{-}+2 \mathrm{Cl}^{-}+3 \mathrm{H}^{+}$

同樣の順序にて反鷹力淮行して行くも, 第 2 段階の反應が此較的 速かに行はれるため, HJO 生成反應つ終了點が電哐曲線上に現 れて來る. 然しそれ酸性を充分に强くした場合は別として p.H が 3.92 程度にては未だ可なりの反應の幄れがあるため, 此の點 は定量的には区應力゙進まない，之に反して，第3 段階の反應は楆 めて管量的に進行する。

次に，次亞暨素酸ナトリウムの溶液に沃化カリウムを加へて行 く場合は，矢張上記の 3 段階を經て沃素イオンは沃素酸イオン禁 ‘酸化される。

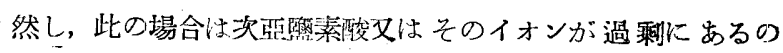
で，第 1 ，第 2 の段階は極好て早く踁過し，電壓曲線上には現れ ない.

斯くして生成した沃素酸イオンに更に沃素イオンを加へて行く 時情

$$
\mathrm{JO}_{3}{ }^{-}+5 \mathrm{~J}^{-}+6 \mathrm{H}^{+}=3 \mathrm{~J}_{2}+3 \mathrm{H}_{2} \mathrm{O}
$$

の反隼によつて沃素を析出する.これは其の溶液の $\mathrm{pH}$ の高くな るに從つて, 笔全には進京孛い。

終に臨み，本呼究中終始御懇篤なる御指導を賜りました石川總 雄敎授に厚ぐ御䄈电し上げます。(昭和 19 年 2 月 18 日受理)

\section{交献}

（1）标詰 12 (昭和 19） 113

（2） 日,化 65 (搠和 19） 313

(3) Kolthoif Rec. Trat. Chim 41 (1922), 615, 740

4) Bray Z. phys. Chem 5\& (1906), 476 